\title{
QUESTIONS CONCERNING THE LEGAL REGULATION OF TELEMEDICINE
}

\author{
A TELEMEDICINA JOGI SZABÁLYOZÁSÁNAK KÉRDÉSEI
}

\author{
FEJES, Zsolt; MIHÓK, Sándor; MATUSZ, Márk Péter \\ (ORCID:0000-0002-1387-2970); (ORCID: 0000-0003-3004-8390); \\ (ORCID: 0000-0002-3768-1079) \\ fejes.zsolt@hm.gov.hu
}

\begin{abstract}
The use of medical diagnostics and therapeutic instruments supported by infocommunication systems is increasingly widespread. These devices are capable of conducting new telemedicine therapeutic methods, remote monitoring system and diagnostic procedures and may serve as additional tools for prevention, as well as health education. However, legal regulation of the area is very difficult owing to technological innovations and the emergence of new fields of application, but is nevertheless indispensable today. We strive to create an objective image that is typical of the current situation.
\end{abstract}

Keywords: telemedicine, sectoral data processing

\begin{abstract}
Absztrakt
Az infokommunikációs rendszerekkel támogatott diagnosztikus vagy terápiás müszerek alkalmazása egyre szélesebb körben képes lehetőséget biztosítani új telemedicinális terápiás módszerek, távfelügyeleti rendszerek és diagnosztikus eljárások végzésére, egyben kiegészítő eszközei lehetnek prevenciós és egészségügyi oktatási tevékenységnek is. A rendszerelemek használatával kapcsolatos jogi szabályozás ugyanakkor - éppen a technikai újdonságok és az új alkalmazási területek megjelenése miatt - csak nehezen képes megfelelni az egyébként szükséges változásoknak. Cikkünkben az aktuális helyzetet korrekten jellemző kép objektív kialakítására törekszünk.
\end{abstract}

Kulcsszavak: telemedicina, szektorális adatkezelés 


\section{INTRODUCTION}

Telemedicine: A structured healthcare service in which the person receiving the service and the person providing the service do not interact directly, they communicate via a remote data transmission system, within the framework of which diagnostic, therapeutic, consultation or remote monitoring activities are performed.[1]

The continuous emergence of new technologies ensuring a telemedicine link and data transmission, the entire transformation of social and individual modes of communication and habits also engendered changes to conventional doctor-patient interactions in all fields of healthcare.[2] The self-regulation of these relationships during the course of routine operations is new for both the doctor and the patient, becomes a part of the interpersonal relationship; however, the lack of clear and explicit regulation of the legal questions that arise may be a barrier to the more widespread use of telemedicine systems. In accordance with the concepts of the strategy of creating a patient-centred healthcare based on sharing information, the Healthcare Electronic Services Space (HESS) programme was launched in Hungary from 1 November 2017 within the scope of activities financed by the National Health Insurance Fund of Hungary (formerly called National Health Insurance Fund), as a result of which the use of telemedicine became widespread, although only in a limited area of use, but nevertheless at a national level. The development of the components regulating the current state of affairs of ehealthcare began in synchrony with the planning phase; however, owing to the unique characteristics of the new systems, it will only be capable of becoming a standard and transparent set of rules handling actual problems that arise in a satisfactory manner during the course of its routine day-to-day operation.

It is important to highlight from a military healthcare perspective that a Medical Communication and Information Systems Expert Panel already operates within NATO that is tasked with assessing telemedicine instruments and their possible use within the framework of the alliance; however, neither does this organisation does not dispose of any standard or agreement that includes legal concepts in connection with telemedicine.[3]

In the present paper, we will present the current issues pertaining to the legal regulation of telemedicine and, in view of the limited space available, what steps the health administration has to take for telemedicine to become a regular healthcare service, without presenting every relevant legal regulation.

\section{INTERNATIONAL OUTLOOK}

A variety of telemedicine applications are widely accessible today in developed countries around the world. The use of telemedicine applications, data processing and patient insurance coverage is regulated by law in 29 states in the USA. Regardless of the regional characteristics of the healthcare service, telemedicine services are financed in $86 \%$ of the states (i.e. are reimbursed by the insurer even if the use of the service is not related to remote reach). From among these services, I would like to highlight the BlueStar diabetes application, which is the first mobile application in the world that doctors may order for patients with diabetes living in the USA, who pay for it.[4] Taiwan also deserves a mention, which country has one the best healthcare systems and infocommunications infrastructure in the world and where telemedicine has played a role in providing services for the rural population ever since 1995.[5] At the same time, there were merely 27,000 mobile telephone users in Nigeria, the economic powerhouse of the African continent, in 2000, which increased to 117 million by 2016 thanks to investments made by a major Chinese company. This naturally only created the technological conditions required for using telemedicine, its widespread use is still some way off.[6] 
However, incredible development may be forecasted in the near future in the worldwide spread of telemedicine, for example in accuracy, as well as miniaturisation and the assessment of large data sets collected based on artificial intelligence. This huge leap is expected from the concept of IoT, i.e. "Internet of Things", according to which we will be using some 30-50 electronic devices worldwide, therefore, 3-7 per household on average, that connect to the Internet. The vast majority of these will be small, smart sensors that are connected to each other and to a server. The healthcare sector will presumably be the primary beneficiary of this technological revolution and, as such, it will, for example, be possible to make smart measurements custom-tailored to the individual at a very low cost. However, this development not only offers exceptional opportunities. We need to understand that the management of such an immensely dense network is riddled with risks and much research and development is needed to eliminate these.[7] According to the research conducted in 114 countries by WHO in 2011, legal and political factors represent one of the greatest barriers to the spread of telemedicine. This, on the one hand, includes data protection, ethical and confidentiality issues and, on the other hand, licensing and defining rules and legal liability. Technical problems (hardware, software) and malpractice ensuing from these are relevant in the latter case. It is an interesting fact that legal matters, which, in particular, affect developed countries, are the second most frequent factor impeding its global spread. Gaps in legal regulations in over 60 percent of the European countries that took part in the research form a barrier.[8]

\section{THE PRESENT OF TELEMEDICINE IN HUNGARY AND FUTURE PATHS}

Five financed telemedicine services are currently available in Hungary, one related to ECG monitoring and four to EEG.[9] At the same time, there are also individually financed telemedicine services, such as, the service offered by the teleradiology centre[10] and its use for the purpose of assessing findings or distant consultation.[11]

Based on the above, it is possible to establish that, owing to various socio-economic characteristics, telemedicine services are not yet widespread in Hungary to a similar extent as, for example, in the U.S., but the Hungarian healthcare sector has also stepped on the path of development. Healthcare in Hungary follows three paths:

- service providers specialising in issuing a second opinion, arranging remote consultations are also present in Hungary;

- more and more institutions (e.g. University of Pécs, Faculty of Medicine Surgery Clinic, Uzsoki Street Hospital) have begun developing applications to improve the patient experience and patient information;

- the state healthcare system has also stepped on this path by setting up HESS mentioned in the introduction to store medical data digitally in a central system, from which not only doctors and pharmacists, but also the patients are able to access their medical records.

Although the latter two systems cannot, in the true sense of the word, be considered solutions offering widespread telemedicine services, they nevertheless represent a milestone in the history of the development of e-healthcare in Hungary. The application developed by a given institution primarily demonstrates openness toward the new technology, which, moreover, was well received by enthusiastic patients keen on downloading the application. While the state HESS initiative is an explicitly essential framework for telemedicine services relying on patient data[12], since it is a modern and standard informatics environment, a communication space using cloud-based technology that connects health service providers, including, hospitals, outpatient clinics, GPs and pharmacies, by providing the highest level of data and cyber 
protection currently available. The system logs every event by recording user data, time, type of and enabling access and the given medical document. Anyone is able to view and monitor all attempts made to access his/her data, even unsuccessful queries.[13]

\section{CURRENT ISSUES OF THE LEGAL REGULATION OF TELEMEDICINE IN LIGHT OF DATA SECURITY AND PERSONALITY RIGHTS}

E-healthcare applications and, as such, telemedicine, raise numerous questions of a legal nature. We wish to outline the legal regulations adopted in connection with telemedicine through data protection and the protection of personality rights. Within the right to protection of personal data, issues relating to the processing of medical data are exceptionally prioritised everywhere around the world within the scope of so-called sectoral data processing. Data pertaining to the state of health of a given person (findings, discharge summaries, medical records, referral forms, expert opinions, medical care forms) is deemed special, sensitive data in every case.

Hungarian legal regulations (equally) comply with European expectations by providing relevant guidance for law enforcers; however, it is nevertheless a fact that the system is complex and, as such, is in many cases difficult to understand for ordinary citizens. Lawmakers and society have great expectations in connection with the processing of medical data, that the data subject (ill or healthy, but nevertheless a person with a medical record):

- may freely dispose of the fate of his/her data;

- receive information on who and based on what authorisation processes, uses her/his data;

- is unable to technically alter the original data recorded during the course of processing;

- at the same time, for the data to only be accessible and useable to the extent necessary and by the persons authorised.

Therefore, medical information by no means to be accessed by any unauthorised person is a fundamental expectation, since there may be serious, unpredictable possible consequences of the breach of data processing principles and rules in terms of the patient's private sphere and, as such, patient rights. The list of negative consequences is extensive, from minor inconveniences through to quite tragic consequences. (For example, access to medical records when the private health service provider is transformed or ceases to operate causes a great deal of confusion in the healthcare system under reform. In this context, neither the responsibility of the doctor nor that of the medical service provider can be ignored)[14] Naturally, lawmaking in European countries and, as such in Hungary, must keep pace with technological development and regulate the general security aims expected from e-healthcare solutions and, as such, from telemedicine, through legal means, i.e.:

- reliability,

- confidentiality,

- authenticity and

- availability.[15]

Therefore, protecting data pertaining to state of health from unauthorised access is a matter of life or death in terms of the future of telemedicine. This data is more frequently becoming the target of similar breaches. According to an international report published by KPMG, the healthcare sector was the target of identified cyber attacks in four out of ten cases. The data stolen has a greater value on the black market than financial data does, since it is possible to block a credit card in minutes; however, it is not possible to change a medical history. It is 
possible to send unsolicited advertisements to patients in a targeted manner based on the list recording illnesses, treatment and the medication taken, which may also be used to blackmail or for a targeted attack. Both the developing companies and the institutions using wireless devices have a huge responsibility, since security may truly be a matter of life and death.

The entry into force of the European General Data Protection, GDPR, on 25 May 2018 represents a key milestone, which classifies personal medical data in a high level protection category and motivates companies to create adequate level security by seriously sanctioning them.[16]

\section{THE E-PROTOCOL AS THE BASIS OF "(LEGAL) SECURITY"}

We presented above the general data and personality rights protection expectations that form the basis of the telemedicine service. In the following, we will review the legal issues relating to the practical use of telemedicine. It is only possible to reliably assess arguments for and against the use of telemedicine in possession of empirical experience, which is why it is (would be) important to set up pilot projects and present, evaluate results.

Procedures applied in healthcare are approved by the health administration in agreement with professional associations based on the recommendation of the Medical Research Council; this is what we call a national guideline. It does not describe the compulsory or strongly recommended procedure in detail, since it depends on the specific infrastructure, professional background. At the same time, the protocol is a "custom-tailored" guideline valid in the given institution, depending on its decision. Obviously, the protocol may not conflict with the professional guideline. During the course of the use of telemedicine, it is expected to be safe for every player, namely, the patient, the doctor (health service provider) and the technical support staff. Cost-efficient and resource-saving use, as well as the legal and financial regulatory framework must also be ensured. The e-protocol (the version of the protocol applicable to telemedicine) is the extension of the standard guideline to treatment with telemedicine instruments. E-protocols overseen and approved by the professional supervisory organisation and authorities would imply legal and financial predictability for the doctor, the health service provider and security. It would also mean legal protection, since it would be enough to compare the documented procedure that took place to the protocol during the course of any future legal procedure. It at the same time offers financial security, since it would be possible to develop much sounder investment and business plans if the given procedure is financed by the social security system. It is an important aspect that the regular review and evaluation of e-protocols becomes far more easier to manage by analysing the data recorded within the framework of automatic data collection. According to current experience, one of the greatest barriers to the use of telemedicine relates to unresolved legal, ethical and financing issues. The lack of professional guidelines among participants, e-protocols equally accepted by the justice administration has to be replaced with civil law, services agreements, which write down what services both the health service and telemedicine service provider provides and under what conditions, but at the same time equally states what the agreement does not cover, as such, attempts to exclude the possibility of subsequent disagreement.[17]

\section{CONCLUSIONS}

The development of information technology has enabled us to work easily, quickly and with precision in the field of healthcare as well. The question today is not whether telemedicine needs to be integrated into routine medical practice, but whether it is possible to maintain the system of healthcare services without the routine use of telemedicine as approved by the social security system. 
It is an effective and cost-efficient mode of treatment according to experts of telemedicine, but the breakthrough has yet to come in its introduction, even though this system constitutes an essential precondition for treatment in the modern era as we move forward in the age of computers. However, the matter of the scope of responsibility of the health service provider providing the service still remains unclear owing to the shortfalls of legal regulation in Hungary, as such, they are understandably afraid of using telemedicine.

The professional guideline in conventional medicine clearly provides protection for doctors in the case of a possible legal procedure, if they complied with it. This does exist in the case of certain services if telemedicine is used; however, are a very long way from becoming standards accepted by the profession and law. It is unclear what claim the patient may make in connection with services, which is why both the patient and the doctors may feel highly vulnerable in the case of a problematic case.[18] The way in which the IT protection of healthcare institutions in Hungary is not satisfactory and that the Internet of Things (IoT) is at a low standard, for example, in the area of smart barcelets, complicates the situation even further. A handful of companies have joined forces and cooperate of develop data protection market standards in connection with the use of medical devices. [19]

According to Eric Topolt, cardiologist and internationally acclaimed researcher of digital healthcare: in the not too distant future of digital healthcare, the doctor will be the decisionmaker (CEO), while the patient will be the operation manager (COO) monitoring the function of his/her organisation, responsible for data collection conducted by the IT department and from time to time reporting its state to the CEO.[20] However, among others, a legal background enabling the widespread use of telemedicine services is still needed to achieve this in Hungary.

\section{BIBLIOGRAPHY}

[1] "What is Telemedicine?". Washington, D.C.: American Telemedicine Association. Retrieved 21 August 2011

[2] Zsolt Fejest Új lehetőség a védelem-egészségügyi ellátásban: telemedicina. (New Opportunity in Defence Healthcare: telemedicine) HADMÉRNÖK (MILITARY ENGINEER): (1) pp. 233-239 (2016)

[3] Fejes Zsolt: Ibid, pp. 233-239

[4] Dr Dóra Bokor: A telemedicina jelene és jövője (The Present and the Future of Telemedicine)

http://medicalonline.hu/informatika/cikk/a_telemedicina_jelene_es_jovoje, Retrieved: 1 September 2017

[5] [aiwan-healthcare https://expo.taiwan-healthcare.org/ Retrieved: 20 October 2017

[6] Ráhel Czirják - Zruzsina Simigh - Eszter Polyák Geo-Debate concept paper: Kína újragyarmatosítja-e Afrikát? (Is China re-colonising Africa?), published by: Pallas Athene Geopolitical Foundation (P AGEO) http://www.pageobudapest.hu/materials 8 p., Retrieved: 20 October 2017

[7] Dr Dóra Bokor: Ibid 
[8] Attila Bán: A telemedicina néhány földrajzi vonatkozása Magyarország példáján (A Few Geographical Aspects of Telemedicine Through the Example of Hungary), PhD thesis, Doctoral Programme, Faculty of Natural Sciences and Computer Science, University of Szeged, Szeged 2017, http://doktori.bibl.uszeged.hu/4031/1/ban_attila_doktori_disszertacio.pdfp. 35., p. 37., Retrieved: 1 September 2017

[9] See: Az egészségügyi szakellátás társadalombiztosítási finanszírozásának egyes kérdéseiről szóló 9/1993. (IV. 2.) NM rendelet 2. számú melléklet (Annex 2 to Ministerial (Ministry of Welfare) Decree 9/1993 (of 2 April) on certain matters relating to the social security financing of specialised healthcare services) http://njt.hu/cgi_bin/njt_doc.cgi?docid=18771.340110, Retrieved: 1 September 2017

[10] Teleradiology, remote diagnosis of digitalised images is the most widespread use of telemedicine in Hungary. Ministerial (Ministry of Health, Social and Family Affairs) Decree 60/2003 (of 20 October) on the minimum professional criteria for providing healthcare services only additionally mentions oncology teleconsultation and ophthalmology. Dr Zoltán Kökény: Telewound care 2.0, telemedicina a sebkezelésben (Telewound Care 2.0, Telemedicine in the Treatment of Wounds), Magyarországi Otthonápolási és Hospice Egyesület XVIII. Otthoni Szakápolási Kongresszusa 2016. október (18th Home Care Congress of the Hungarian Homecare and Hospice Association, October 2016), p. 4 http://mohe.hu/xviii.-otthoni-szakapolasi-kongresszus-eloadasokanyagai, Retrieved: 1 September 2017

[11] Dr Dóra Bokor: Ibid

[12] Dr Andrea Ficzere: Zsebben hordott orvosarzenál (Medical Arsenal in the Pocket), http://betegfokusz.blog.hu/2017/07/21/zsebben_hordott_orvosarzenal\#more12678149,

Retrieved: 1 September 2017

[13] https://e-egeszsegugy.gov.hu/eeszt, Retrieved: 1 September 2017

[14] Júlia Sziklay: Betegjogi adatvédelem „Beteg vagy egészségügy”: a betegjogok helyzete egy átalakuló rendszerben, avagy kinek fontos a beteg?: az alapvető jogok biztosának konferencia kiadványa (Patient Data Protection Rights, Patient or Healthcare: the Status of Patient Rights in a System under Reform, or Who Is the Patient Important to?: publication of the conference of the Commissioner for Fundamental Rights) / [edited by: Beáta Borza]; [published by: Office of the Commissioner for Fundamental Rights] pp. 123-125 http://nektar1.oszk.hu/LVbin/LibriVision/lv_view_records.html, Retrieved: 1 September 2017

[15] Andrea Kő - Zoltán Szabó: Innovatív e-egészségügyi megoldások - a jövő internetes technológiái a távmonitoringozásban (Innovative E-healthcare Solutions in the Future Technological and Remote Monitoring of the Internet) http://unipub.lib.unicorvinus.hu/2322/1/PPB2015n4p6.pdf p. 14, Retrieved: 1 September 2017

[16] Tízből négy kibertámadásnak az egészségügy a célpontja, (Four out of Ten Cyber Attacks Target

Healthcare) http://medicalonline.hu/informatika/cikk/tizbol_negy_kibertamadasnak_az_egeszsegug y_a_celpontja, Retrieved: 17 October 2017 
[17] Dr László Daragó - Zsófia Jung - Fanni Ispán - Rita Bendes - Dr Elek Dinya: A telemedicina előnyei és hátrányai, Összefoglaló Közlemény (The Advantages and the Disadvantages of T elemedicine, Summary Report) http://akademiai.com/doi/pdf/10.1556/OH.2013.29664 DOI: 10.1556/OH.2013.29664, 2013, Volume 154, Issue 30, p. 1170, Retrieved: 1 September 2017

[18] Egészségügyi eszközök a kíbertámadások célkeresztjében (Healthcare Devices in the Line of Fire of Cyber Attacks)

http://medicalonline.hu/informatika/cikk/egeszsegugyi_eszkozok_a_kibertamadasok_ce lkeresztjeben, Retrieved: 1 September 2017

[19] Dr László Daragó - Zsófia Jung - Fanni Ispán - Rita Bendes - Dr Elek Dinya: Ibid, pp. 1169-1170 [20] Dr Dóra Bokor: Ibid 